\title{
Geochemical Discriminant for Provenance Characterization and Palaeogeography of Shales from Dahomey Embayment, Southwestern Nigeria
}

\author{
0. Innocent Ejeh \\ Department of Geology, Delta State University, Abraka, Nigeria \\ Email: ejehoi@gmail.com, oiejeh@delsu.edu.ng
}

Received 31 March 2016; accepted 11 June 2016; published 14 June 2016

Copyright (C) 2016 by author and Scientific Research Publishing Inc. This work is licensed under the Creative Commons Attribution International License (CC BY). http://creativecommons.org/licenses/by/4.0/

(c) (i) Open Access

\begin{abstract}
The geochemical compositions [major, trace and Rare Earth Elements (REE)] of CretaceousTertiary shales from Gbekebo-1 well were used to characterize provenance, paleogeography, source area weathering and tectonic setting of the study area located in the southwestern part of the Dahomey Embayment, Nigeria. Core samples (eight) of shales were obtained and analyzed geochemically using the combined methods of major elements Fusion Inductively Coupled Plasma (FUS-ICP) and trace elements Fusion Inductively Coupled Plasma Emission/Mass Spectrometry (FUS-ICP/MS). An A-CN-K $\left(\mathrm{Al}_{2} \mathrm{O}_{3}-\mathrm{CaO}+\mathrm{Na}_{2} \mathrm{O}-\mathrm{K}_{2} \mathrm{O}\right)$ ternary plot, geochemical discriminant function of major elements and chondrite normalized plots of REE suggest an upper continental crust provenance of felsic to intermediate or mixed igneous rocks of tonalite to granodiorite composition. High values of chemical index of alteration (CIA, 82.22 - 96.39) and chemical index of weathering (CIW, 88.10 - 99.17) indicated a palaeogeographic condition marked by wet tropical climate where intense chemical weathering and erosion prevailed. The Cretaceous-Tertiary shales from Gbekebo-1 well are inferred to have been deposited in passive margin setting based on various geochemical tectonic setting discrimination diagrams.
\end{abstract}

\section{Keywords}

Geochemistry, Shale, Provenance, Paleogeography, Dahomey Embayment

\section{Introduction}

The compositional characteristics of shales are often determined by the effects of surface processes (weathering,

How to cite this paper: Ejeh, O.I. (2016) Geochemical Discriminant for Provenance Characterization and Palaeogeography of Shales from Dahomey Embayment, Southwestern Nigeria. Journal of Geoscience and Environment Protection, 4, 56-68. 
erosion, transportation) on their source rock(s) and subsequent diagenesis [1] [2]. Weathering, erosion, sediment recycling and diagenesis often affect the alkalis $\left(\mathrm{Na}_{2} \mathrm{O}\right.$ and $\left.\mathrm{K}_{2} \mathrm{O}\right)$ and the alkali-earth elements $(\mathrm{CaO}$ and $\mathrm{MgO})$; whereas $\mathrm{Al}_{2} \mathrm{O}_{3}, \mathrm{TiO}_{2}$, the high field strength elements (HFSE) (Co, Sc, Hf, Ta, $\mathrm{Nb}$, Ti and $\mathrm{Y}$ ) and some other trace elements are geochemically immobile in nature and are widely known as provenance diagnostic [3]. Very fine grained sediments such as clays or shales are often analyzed for their geochemical attributes with the assumption that they match closely average composition of the upper continental crust [4]. This assumption is based on the fact that thorough mixing occurs in very fine grained sediments, which often host Rare Earth Elements (REE) and Th that are relatively immobile; as such preserve the source rock composition.

In this study, the geochemistry of shale samples from Gbekebo- 1 well, southwestern, Nigeria was applied to characterize provenance, paleogeography and source area weathering/tectonic setting of the study area (Figure 1). Geochemical studies aimed at characterizing provenance, inferring sediment source area(s) weathering/ tectonic setting and palaeogeography of the Dahomey Embayment that are based on subsurface data sets are rare (e.g. [5]), probably due to inadequate data availability or poor exposures [6]. Since the discovery of oil seeps and tar sands in the Okitipupa area, much effort has been put into exploring the hydrocarbon potentials of the Dahomey embayment [7]-[11]. A number of exploration wells (such as Gbekebo-1, Afowo-1, Araromi-1, Benin west-1, Ife-1, Ore-1, Ise-1, Ojo-1, Lekki-1, etc.) were drilled by Shell d'Arcy (1936-1960), Tennessee Inc (1960-1966) and other firms/agencies. These exploration wells were all dry holes with minor showings of tarry oil and oil sands at varied depths up to the basement [12]. However, large reserves of bitumen have been proven in tar sands deposits of the Abeokuta Group [13]. Furthermore, although no commercial oil discovery was made onshore, the offshore section of the embayment offered a ray of successful discoveries such as the Aje Field.

\section{Geological Setting}

The Dahomey Embayment is part of the Gulf of Guinea province that comprises Benin, Keta, Central, Saltpond,

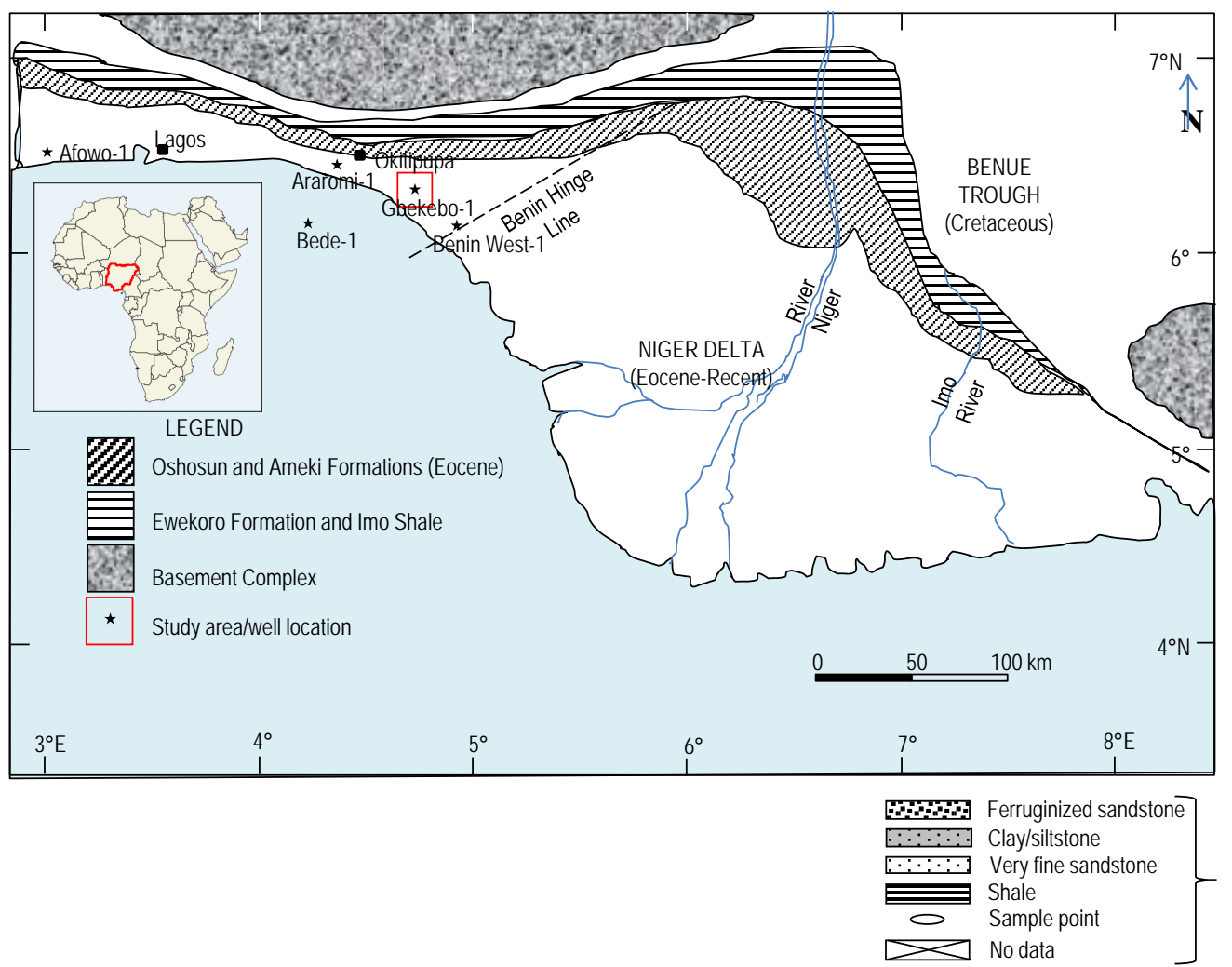

Gbekebo-1 well

Figure 1. Simplified geological map of the Nigeria section of the Dahomey Embayment (Redrawn after [41]) with a simplified lithologic log of Gbekebo-1 on the right hand side. 
Tano and Ivory Coast sub-basins [14]. The province is bounded to the east by the Niger Delta province [15] and in the west by the West African Coastal province. The east-west structurally aligned sub-basins in the Gulf of Guinea are divided into three transform fault zones (FZ): St Paul FZ (at northwestern side); Romanche FZ (demarcating Ivory Coast, saltpond and Tano from Keta and Benin sub-basins); and Chain FZ (along the eastern part of the province). The province is a wrench-modified basin, formed at the termination of the tectonic event that lasted from Late Jurassic to Early Cretaceous. This tectonic event marked by transform and block faulting was operational throughout the entire Paleozoic leading to the break-up of the American (north and South) from African palaeo-continents [16]. A three-stage development of the basin has thus been suggested, namely: i) Pre-rift or pre-transform or intra-cratonic stage (Late Proterozoic to Late Jurassic), ii) Syn-rift or syn-transform or rift stage (Late Jurassic to Early Cretaceous) and iii) Post-rift or post-transform or drift stage (Late Cretaceous to Holocene) [17]-[20].

The stratigraphy of the Dahomey embayment has been discussed by a number of workers such as [21]-[25], amongst others. The sedimentary successions of this basin ranged from Cretaceous to Recent. The stratigraphic package is broadly divided into the Cretaceous Abeokuta Group (Ise, Afowo, and Araromi Formations) and Cenozoic units (Ewekoro, Akinbo, Oshosun, Ilaro, Ogwashi-Asaba and Benin Formations) [23] [26]. Rocks of the pre-transform stage in the Benin and Dahomey Embayment constitute the lower part of Ise Formation (Figure 2) composed of conglomerates, sandstones, shales of fluvio-deltaic environment [14] [17] [23]. The Afowo Formation at its type section (Afowo-1 well, Figure 2) comprised medium to coarse sandstones with thick to thin intercalations of siltstones and claystones; while the Araromi Formation (Maastrichtian to Paleocene) (type section Araromi-1 well, Figure 1) is marked by shale units similar to Awgu and Nkporo shales. At the base, this formation exhibited shale thickening seaward with siltstone, limestones and marl. Overlying the Araromi Formation is the Ewekoro which consist of limestone, shales and mudstone/claystone. Akinbo Formation is shaly with some clay interbeds, nodules of calcareous and phosphatic materials, impure limestone and glauconite [27]. The Oshosun Formation is made up of greenish clays and glauconitic shales intercalated with sandstones and limestones [5]. The Oshosun Formation is overlain by Ilaro, Ogwashi-Asaba and Benin Formations all of which consist of medium to coarse sands, alternating sands and clays, coastal plain sands respectively. A NNW-SSE correlation sketch involving Ise-1, Gbekebo-1, and Benin West-1 (Figure 2) indicated that these wells penetrated Araromi, Ewekoro, Oshosun and Ogwashi-Asaba/Benin Formations.

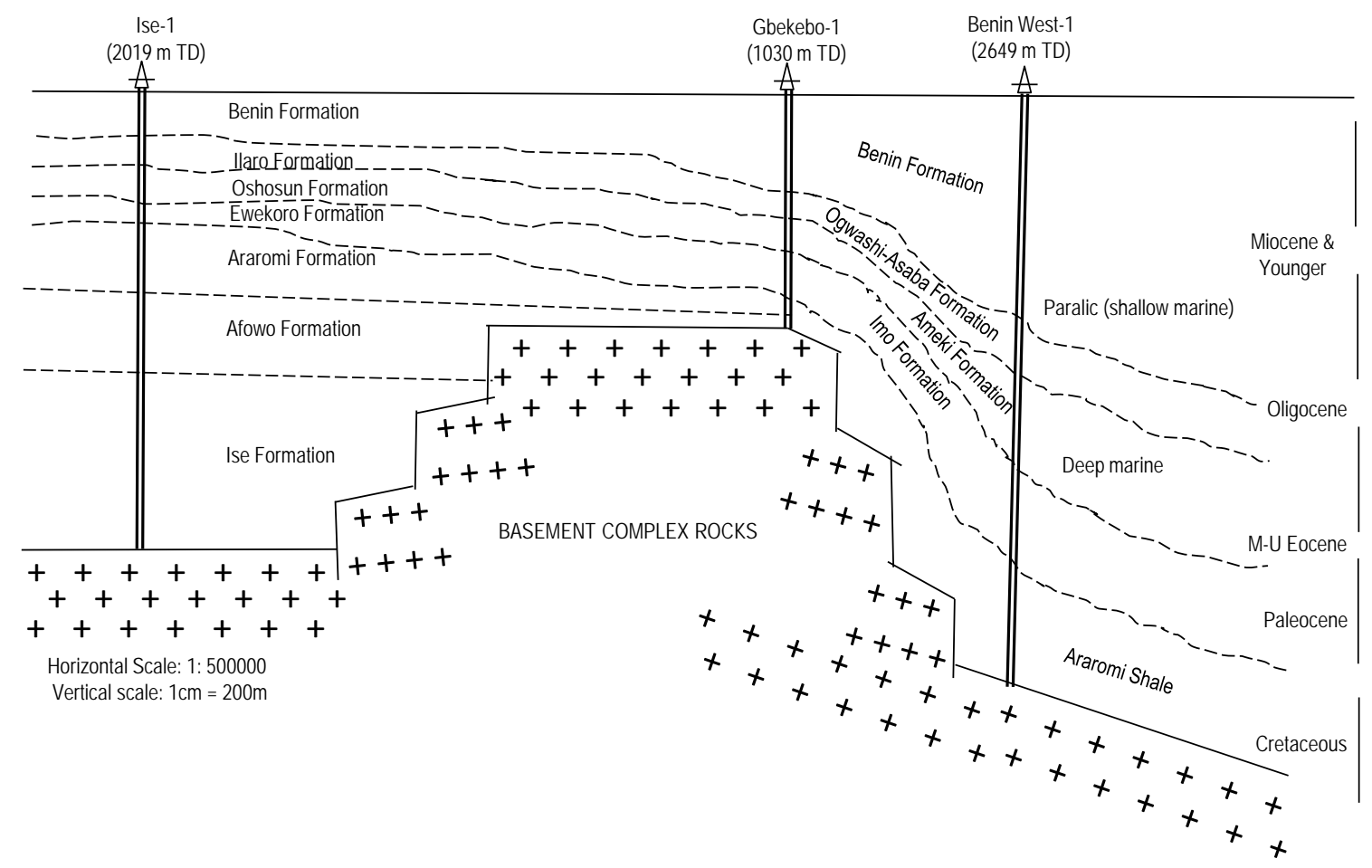

Figure 2. A NNW-SSE correlation of wells drilled in the Dahomey Embayment (modified after [23]). 


\section{Samples and Analytical Methods}

Eight core samples of shale obtained at different depths from Gbekebor-1 well (Figure 1) were analyzed for fifty-five elemental components (10 major and 45 trace/REE) using the combined methods of Fusion Inductively Coupled Plasma (FUS-ICP) and Fusion Inductively Coupled Plasma emission/Mass Spectrometry (FUS-ICP/ MS). Pre-analytical sample preparation that included crushing with agate mortar and pestle were undertaken at the Geology laboratory, Delta State University, Abraka; following which the samples were packaged and sent to the Activation laboratories, Ontario, Canada for the FUS-ICP and FUS-ICP/MS analyses. Details of FUS-ICP and FUS-ICP/MS are as reported by [28] and [29] respectively. Prior to the laboratory analyses (ICP-MS) more than $95 \%$ of each sample was ground so as to pass through a 200 mesh for a complete fusion of even the resistant minerals that may be present. Next, the main analyses involved the use of lithium metaborate/tetraborate fusion, followed by ICP and ICP/MS. Quality control technique was ensured through mass balance and elemental totals of oxides is usually between $98 \%$ to $101 \%$.

\section{Results and Interpretations}

\subsection{Major Elements}

Results of major elements (oxides in wt \%) are listed in Table 1 alongside average values of North American Shale Composite (NASC) [30] and Post-Archean Australian Shale (PAAS) [4] for comparison. The major elements compositions of the shales vary widely. The range and average values of major elemental oxides are as follows: $\mathrm{SiO}_{2}$ (40.96 - 54.18, average 46.61), $\mathrm{Al}_{2} \mathrm{O}_{3}$ (12.9 - 24.51, average 18.89), $\mathrm{Fe}_{2} \mathrm{O}_{3}{ }^{\mathrm{T}}$ (5.41 - 7.37, average 6.15), $\mathrm{MgO}$ (0.13-5.94, average 2.25), $\mathrm{TiO}_{2}$ (0.69 - 1.42, average 0.96), $\mathrm{MnO}(0.009$ - 0.106, average 0.045), $\mathrm{CaO}\left(0.08\right.$ - 5.24, average 1.92), $\mathrm{Na}_{2} \mathrm{O}(0.06-0.60$, average 0.28$), \mathrm{K}_{2} \mathrm{O}(0.64-1.45$, average 1.07$)$, and $\mathrm{P}_{2} \mathrm{O}_{5}$ (0.07 - 0.44, average 0.15). Loss on ignition (LOI) values ranged from 13.98 - 25.92 wt\%. The major oxides showed enrichment ( $>1$ wt\%) in $\mathrm{SiO}_{2}, \mathrm{Al}_{2} \mathrm{O}_{3}$, and $\mathrm{Fe}_{2} \mathrm{O}_{3}{ }^{\mathrm{T}}$; whereas the alkalis $\left(\mathrm{Na}_{2} \mathrm{O}\right.$ and $\left.\mathrm{K}_{2} \mathrm{O}\right)$ and alkali-earth elements ( $\mathrm{MgO}$ and $\mathrm{CaO})$ and other elements indicated slight enrichment to depletion. A plot of $\log \left(\mathrm{SiO}_{2} / \mathrm{Al}_{2} \mathrm{O}_{3}\right)$ versus $\log \left(\mathrm{Fe}_{2} \mathrm{O}_{3} / \mathrm{K}_{2} \mathrm{O}\right)$ proposed by [31] for chemical classification of sedimentary rocks reveals that the shale samples from Gbekebo-1 well plotted within the shale and Fe-shale fields (Figure 3).

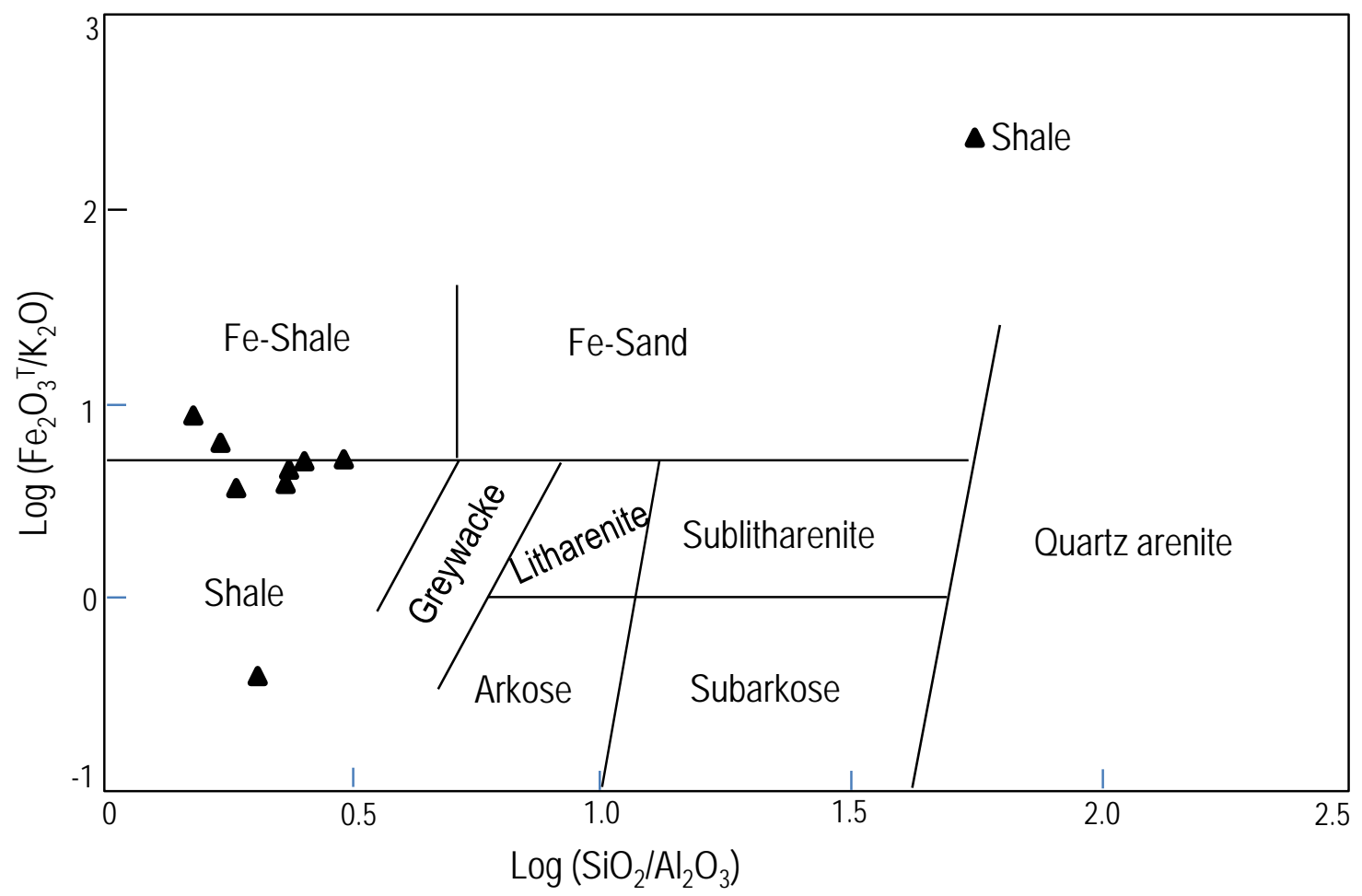

Figure 3. Chemical classification of shales from Gbekebo-1 well (classes of fields after [31]). 
Table 1. Major elements compositions (in wt\%) of shale samples from Gbekebo-1 well.

\begin{tabular}{|c|c|c|c|c|c|c|c|c|c|c|}
\hline Sample code & Gbk_1 & Gbk_2 & Gbk_3 & Gbk_4 & Gbk_5 & Gbk_6 & Gbk_7 & Gbk_8 & NASC & PAAS \\
\hline $\begin{array}{l}\text { Depth (m) } \\
\text { range }\end{array}$ & $34.7-35.7$ & $243.5-244.8$ & $341.7-342.6$ & $573-573.8$ & $590-591$ & 779 - 780.6 & 955.5 - 956.5 & 997.9 - 998.8 & & \\
\hline Formation & Benin & Ogwashi-Asaba & Oshosun & Ewekoro & Ewekoro & Ewekoro & Araromi & Araromi & & \\
\hline Lithology & Shale & Shale & Shale & Shale & Shale & Shale & Shale & Shale & & \\
\hline $\mathrm{SiO}_{2}$ & 48.09 & 54.18 & 40.96 & 51.18 & 47.98 & 44.15 & 44.70 & 41.65 & 64.80 & 62.80 \\
\hline $\mathrm{TiO}_{2}$ & 0.942 & 1.357 & 1.420 & 0.691 & 0.783 & 0.727 & 0.857 & 0.933 & 00.70 & 01.00 \\
\hline $\mathrm{Al}_{2} \mathrm{O}_{3}$ & 17.03 & 22.97 & 24.51 & 12.90 & 15.57 & 15.07 & 21.14 & 21.91 & 16.90 & 18.90 \\
\hline $\mathrm{Fe}_{2} \mathrm{O}_{3}{ }^{\mathrm{T}}$ & 06.01 & 5.750 & 6.330 & 5.410 & 6.090 & 5.850 & 6.410 & 7.370 & 05.65 & 07.22 \\
\hline $\mathrm{MnO}$ & 0.024 & 0.106 & 0.032 & 0.051 & 0.072 & 0.053 & 0.012 & 0.009 & 00.06 & 00.11 \\
\hline $\mathrm{MgO}$ & 0.130 & 0.650 & 0.300 & 5.900 & 4.450 & 4.860 & 1.120 & 0.590 & 02.86 & 02.20 \\
\hline $\mathrm{CaO}$ & 0.080 & 0.200 & 0.140 & 0.420 & 2.890 & 5.740 & 1.220 & 4.670 & 03.63 & 01.30 \\
\hline $\mathrm{Na}_{2} \mathrm{O}$ & 0.080 & 0.070 & 0.060 & 0.370 & 0.370 & 0.600 & 0.460 & 0.250 & 01.14 & 01.20 \\
\hline $\mathrm{K}_{2} \mathrm{O}$ & 1.240 & 1.350 & 0.640 & 0.820 & 1.030 & 1.090 & 1.450 & 0.960 & 03.97 & 03.70 \\
\hline $\mathrm{P}_{2} \mathrm{O}_{5}$ & 0.080 & 0.080 & 0.070 & 0.070 & 0.110 & 0.250 & 0.100 & 0.440 & 00.13 & 00.16 \\
\hline LOI & 25.35 & 13.99 & 25.92 & 21.44 & 19.90 & 21.19 & 21.05 & 19.71 & - & - \\
\hline Total & 99.07 & 100.7 & 100.4 & 99.26 & 99.24 & 99.58 & 98.52 & 98.48 & & \\
\hline $\mathrm{MgO}+\mathrm{Fe}_{2} \mathrm{O}_{3}{ }^{\mathrm{T}}$ & 6.140 & 1.300 & 6.630 & 11.31 & 10.54 & 10.71 & 7.530 & 7.960 & & \\
\hline $\mathrm{Fe}_{2} \mathrm{O}_{3}{ }^{\mathrm{T}} / \mathrm{K}_{2} \mathrm{O}$ & 4.847 & 0.481 & 9.891 & 6.598 & 5.913 & 5.367 & 4.421 & 7.677 & & \\
\hline $\mathrm{Al}_{2} \mathrm{O}_{3} / \mathrm{TiO}_{2}$ & 18.08 & 16.93 & 17.26 & 18.67 & 19.89 & 20.73 & 24.67 & 23.48 & & \\
\hline $\mathrm{K}_{2} \mathrm{O} / \mathrm{Na}_{2} \mathrm{O}$ & 15.50 & 19.29 & 10.67 & 2.216 & 2.784 & 1.817 & 3.152 & 3.840 & & \\
\hline $\mathrm{SiO}_{2} / \mathrm{Al}_{2} \mathrm{O}_{3}$ & 2.824 & 2.359 & 1.671 & 3.967 & 3.082 & 2.930 & 2.114 & 1.901 & & \\
\hline \multicolumn{11}{|l|}{ Moles } \\
\hline $\mathrm{SiO}_{2}$ & 0.800 & 0.902 & 0.682 & 0.852 & $0.798^{`}$ & 0.735 & 0.744 & 0.693 & & \\
\hline $\mathrm{Al}_{2} \mathrm{O}_{3}$ & 0.167 & 0.225 & 0.240 & 0.127 & 0.153 & 0.148 & 0.207 & 0.215 & & \\
\hline $\mathrm{CaO}^{*}$ & 0.001 & 0.001 & 0.001 & 0.006 & 0.006 & 0.010 & 0.007 & 0.004 & & \\
\hline $\mathrm{Na}_{2} \mathrm{O}$ & 0.001 & 0.001 & 0.001 & 0.006 & 0.006 & 0.010 & 0.007 & 0.004 & & \\
\hline $\mathrm{MgO}$ & 0.003 & 0.016 & 0.007 & 0.146 & 0.110 & 0.121 & 0.028 & 0.015 & & \\
\hline $\mathrm{Fe}_{2} \mathrm{O}_{3}$ & 0.038 & 0.036 & 0.040 & 0.034 & 0.038 & 0.037 & 0.040 & 0.046 & & \\
\hline $\mathrm{K}_{2} \mathrm{O}$ & 0.013 & 0.014 & 0.007 & 0.009 & 0.011 & 0.012 & 0.015 & 0.010 & & \\
\hline $\mathrm{CaO}^{*}+\mathrm{Na}_{2} \mathrm{O}$ & 0.002 & 0.006 & 0.003 & 0.004 & 0.004 & 0.020 & 0.021 & 0.002 & & \\
\hline $\mathrm{Fe}_{2} \mathrm{O}_{3}+\mathrm{MgO}$ & 0.041 & 0.052 & 0.047 & 0.180 & 0.148 & 0.158 & 0.068 & 0.061 & & \\
\hline $\begin{array}{c}\mathrm{CaO}^{*}+ \\
\mathrm{Na}_{2} \mathrm{O}+\mathrm{K}_{2} \mathrm{O}\end{array}$ & 0.015 & 0.020 & 0.010 & 0.013 & 0.015 & 0.032 & 0.036 & 0.012 & & \\
\hline CIA & 91.76 & 93.36 & 96.39 & 85.81 & 86.93 & 82.22 & 87.71 & 92.27 & & \\
\hline CIW & 98.82 & 99.12 & 99.17 & 91.36 & 92.73 & 88.10 & 93.67 & 96.41 & & \\
\hline
\end{tabular}




\subsection{Trace Elements}

Table 2 shows the trace elements concentration of the selected shale samples from Gbekebo- 1 well compared with NASC and PAAS alongside their elemental ratios. The trace elements showed wide variability when compared to NASC and PAAS. High enrichment concentration values are recorded by Ba, Sr, Zr, and Cr. The enrichment to slight enrichment exhibited by Y, Zr, Hf, Ta, Th, and U are indications of the presence of heavy minerals (e.g. zircon) that are resistant to weathering, erosion and diagenesis.

\subsection{Rare Earth Elements}

The results of rare earth element (REE) concentration of the shales from Gbekebo-1 well are shown in Table 3. The REE concentration values are comparable to that of PAAS and NASC (Table 3). The REE patterns of the chondrite normalized values are marked by Light Rare Earth Elements (LREE) enrichment, negative Eu anomalies, and a rather flat Heavy Rare Earth Elements (HREE) pattern (Figure 4).

\section{Discussion and Inferences}

\subsection{Geochemistry and Provenance Discrimination}

Using major elemental compositions, provenance can be discriminated into mafic, intermediate, felsic igneous rocks and Quartzose sedimentary rocks fields as reported by [32]. Following this approach by [32] shale samples of the Gbekebo-1 well plot in the mafic and Quartzose sedimentary fields, implying a mixed source area (Figure 5(a)). The ratio of $\mathrm{Al}_{2} \mathrm{O}_{3} / \mathrm{TiO}_{2}$ in shales has been suggested to be similar to that of the source rock [33] as such it is used as an index of provenance. Hayashi et al. [33] stated that ratios that exhibited values greater than twentyone implied that the sediments are of felsic origin. The average values of $\mathrm{Al}_{2} \mathrm{O}_{3} / \mathrm{TiO}_{2}$ for this study is $19.96 \mathrm{wt} \%$ (range from 16.93 to $24.67 \mathrm{wt} \%$ ) indicating felsic to intermediate or mixed sources.

Floyd and Leveridge [34] proposed a plot of La/Th against Hf to discriminate provenance; and in this study the samples plotted in felsic to mixed felsic/basic sources (Figure 5(b)). They are of upper continental crust deposited in passive margin source. McLennan et al. [3] plotted Th versus Sc to infer provenance and when applied in this study the Gbekebo-1 well samples fell mostly in intermediate source with some continental component input (Figure 5(c)). Gu et al. [35] used Co/Th versus La/Sc diagram for provenance discrimination and its application to this study revealed samples plotting close to or above the line at $\mathrm{Co} / \mathrm{Th}=1.27$, an indication of

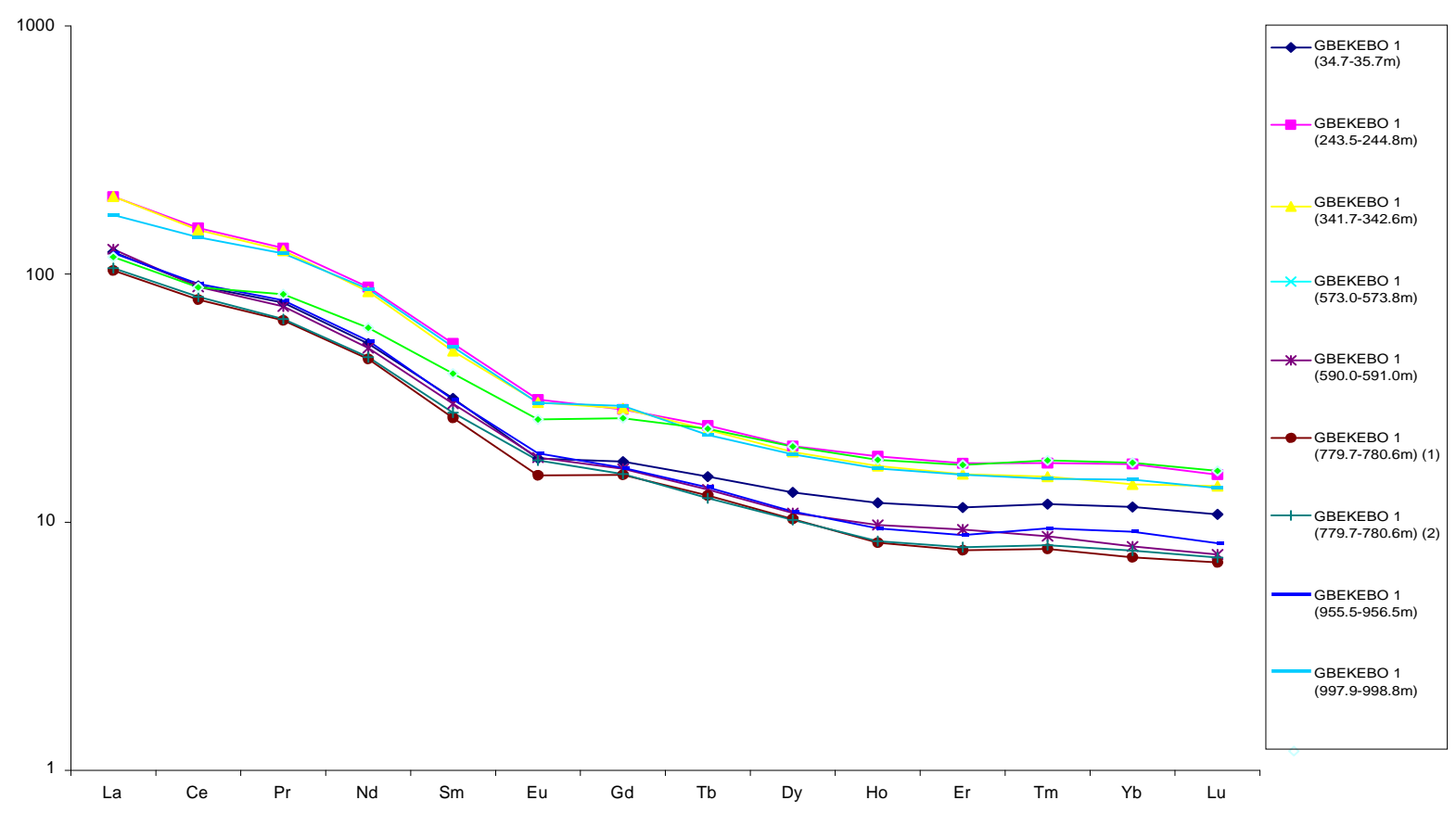

Figure 4. Chondrite-normalized REE patterns of shales from the Gbekebo-1 well. 
Table 2. Trace elements concentration (in ppm) of shale samples from Gbekebo-1 well.

\begin{tabular}{|c|c|c|c|c|c|c|c|c|c|c|}
\hline Sample code & Gbk_1 & Gbk_2 & Gbk_3 & Gbk_4 & Gbk_5 & Gbk_6 & Gbk_7 & Gbk_8 & NASC & PAAS \\
\hline $\begin{array}{l}\text { Depth (m) } \\
\text { range }\end{array}$ & $34.7-35.7$ & $7 \quad 243.5$ - 244.8 & 341.7 - 342.6 & $573-573.8$ & $590-591$ & 779 - 780.6 & 955.5 - 956.5 & 997.9 - 998.8 & & \\
\hline Formation & Benin & Ogwashi-Asaba & Oshosun & Ewekoro & Ewekoro & Ewekoro & Araromi & Araromi & & \\
\hline Lithology & Shale & Shale & Shale & Shale & Shale & Shale & Shale & Shale & & \\
\hline Sc & 11.00 & 18.00 & 18.00 & 11.00 & 13.00 & 12.00 & 18.00 & 17.00 & 15 & 16 \\
\hline $\mathrm{Ni}$ & 30.00 & 50.00 & 40.00 & 30.00 & 50.00 & 50.00 & 50.00 & 70.00 & 58 & 55 \\
\hline $\mathrm{Be}$ & 3.000 & 4.000 & 4.000 & 3.000 & 3.000 & 3.000 & 3.000 & 3.000 & & \\
\hline $\mathrm{Ga}$ & 23.00 & 31.00 & 32.00 & 18.00 & 21.00 & 19.00 & 27.00 & 27.00 & - & - \\
\hline $\mathrm{Nb}$ & 23.00 & 31.00 & 34.00 & 17.00 & 21.00 & 17.00 & 16.00 & 22.00 & 13 & 1.9 \\
\hline $\mathrm{Ba}$ & 526.0 & 421.0 & 402.0 & 1720 & 125.0 & 1343 & 140.0 & 160.0 & 636 & 650 \\
\hline Та & 1.800 & 2.500 & 2.700 & 1.400 & 1.700 & 1.300 & 1.300 & 1.500 & 1.1 & - \\
\hline Co & 11.00 & 19.00 & 14.00 & 14.00 & 15.00 & 12.00 & 16.00 & 14.00 & 26 & 23 \\
\hline $\mathrm{Cu}$ & 20.00 & 20.00 & 20.00 & $<10.0$ & $<10.0$ & $<10.0$ & 20.00 & 20.00 & - & - \\
\hline $\mathrm{Sr}$ & 122.0 & 116.0 & 114.0 & 180.0 & 184.0 & 184.0 & 338.0 & 202.0 & 142 & 200 \\
\hline $\mathrm{V}$ & 77.00 & 128.0 & 108.0 & 117.0 & 183.0 & 157.0 & 194.0 & 172.0 & 130 & 96 \\
\hline $\mathrm{Ge}$ & $<1.00$ & 1.000 & 1.000 & $<1.00$ & 1.000 & $<1.00$ & 1.000 & 1.000 & & \\
\hline Mo & $<2.00$ & 3.000 & 4.000 & $<2.00$ & 3.000 & 2.000 & 5.000 & 13.00 & & \\
\hline As & $<5.00$ & 7.000 & $<5.00$ & $<5.00$ & $<5.00$ & $<5.00$ & 5.00 & 12.00 & & \\
\hline $\mathrm{Ag}$ & 1.700 & 1.400 & 1.300 & 0.600 & 0.700 & 0.600 & 0.600 & 0.800 & & \\
\hline In & $<0.20$ & $<0.20$ & $<0.20$ & $<0.20$ & $<0.20$ & $<0.20$ & $<0.20$ & $<0.20$ & & \\
\hline $\mathrm{Bi}$ & $<0.40$ & $<0.40$ & $<0.40$ & $<0.40$ & $<0.40$ & $<0.40$ & $<0.40$ & $<0.40$ & & \\
\hline Sn & 3.000 & 4.000 & 4.000 & 2.000 & 3.000 & 2.000 & 3.000 & 4.000 & & \\
\hline $\mathrm{Sb}$ & $<0.50$ & 0.600 & $<0.50$ & 0.500 & 0.600 & $<0.50$ & 0.600 & 0.600 & & \\
\hline Cs & 2.800 & 8.100 & 5.500 & 3.500 & 4.200 & 3.900 & 7.000 & 4.600 & & \\
\hline $\mathrm{Zn}$ & 140.0 & 100.0 & 90.00 & 80.00 & 80.00 & 130.0 & 140.0 & 110.0 & - & - \\
\hline Th & 13.20 & 18.00 & 18.70 & 8.600 & 11.10 & 9.000 & 11.80 & 16.10 & - & - \\
\hline $\mathrm{U}$ & 4.400 & 3.700 & 5.800 & 1.700 & 2.400 & 2.700 & 3.100 & 13.30 & - & - \\
\hline $\mathrm{Cr}$ & 100.0 & 140.0 & 130.0 & 90.00 & 170.0 & 160.0 & 190.0 & 250.0 & 125 & 110 \\
\hline $\mathrm{Rb}$ & 46.00 & 85.00 & 49.00 & 42.00 & 51.00 & 46.00 & 66.00 & 61.00 & 125 & 160 \\
\hline $\mathrm{Zr}$ & 367.0 & 297.0 & 273.0 & 127.0 & 157.0 & 143.0 & 124.0 & 219.0 & 200 & 210 \\
\hline Hf & 9.000 & 7.500 & 7.000 & 3.000 & 3.800 & 3.500 & 3.100 & 5.500 & 6.3 & 5.0 \\
\hline $\mathrm{Pb}$ & 15.00 & 22.00 & 19.00 & 15.00 & 14.00 & 12.00 & 13.00 & 11.00 & & \\
\hline TI & 0.300 & 0.400 & 0.500 & 0.100 & 0.100 & $<0.10$ & 0.200 & 0.400 & & \\
\hline W & 1.000 & 2.000 & 2.000 & 1.000 & 1.000 & 1.000 & 1.000 & 11.00 & & \\
\hline $\mathrm{Th} / \mathrm{U}$ & 3.000 & 4.865 & 3.224 & 5.059 & 4.625 & 3.333 & 3.806 & 1.211 & & \\
\hline $\mathrm{Rb} / \mathrm{Sr}$ & 0.377 & 0.733 & 0.430 & 0.233 & 0.277 & 0.250 & 0.195 & 0.302 & & \\
\hline $\mathrm{Cr} / \mathrm{Th}$ & 7.576 & 7.778 & 6.952 & 10.47 & 15.32 & 17.78 & 16.10 & 15.53 & & \\
\hline $\mathrm{Cr} / \mathrm{Zr}$ & 0.272 & 0.471 & 0.476 & 0.709 & 1.083 & 1.119 & 1.532 & 1.142 & 0.63 & 0.52 \\
\hline
\end{tabular}




\section{Continued}

\begin{tabular}{ccccccccc}
\hline $\mathrm{Th} / \mathrm{Sc}$ & 1.200 & 1.000 & 1.039 & 0.782 & 0.854 & 0.750 & 0.656 & 0.947 \\
$\mathrm{Th} / \mathrm{Zr}$ & 0.036 & 0.061 & 0.068 & 0.068 & 0.071 & 0.063 & 0.095 & 0.074 \\
$\mathrm{La} / \mathrm{Th}$ & 2.932 & 3.589 & 3.465 & 3.233 & 3.577 & 3.656 & 3.246 & 3.385 \\
$\mathrm{Co} / \mathrm{Th}$ & 0.833 & 1.056 & 0.749 & 1.628 & 1.351 & 1.333 & 1.356 & 0.870 \\
$\mathrm{La} / \mathrm{Sc}$ & 3.518 & 3.589 & 3.600 & 2.527 & 3.054 & 2.742 & 2.128 & 3.206 \\
$\mathrm{La} / \mathrm{Co}$ & 3.518 & 3.400 & 4.629 & 1.986 & 2.647 & 2.742 & 2.394 & 3.893 \\
$\mathrm{Th} / \mathrm{Co}$ & 1.200 & 0.947 & 1.336 & 0.6143 & 0.740 & 0.750 & 0.738 & 1.150 \\
$\mathrm{Th} / \mathrm{Cr}$ & 0.132 & 0.129 & 0.143 & 0.096 & 0.065 & 0.056 & 0.062 & 0.064 \\
$\mathrm{Ba} / \mathrm{La}$ & 13.59 & 6.517 & 6.204 & 61.87 & 3.149 & 40.82 & 3.655 & 2.936 \\
\hline
\end{tabular}

Table 3. Rare earth elements concentration (in ppm) of shale samples from Gbekebo-1 well.

\begin{tabular}{|c|c|c|c|c|c|c|c|c|c|c|}
\hline Sample code & Gbk_1 & Gbk_2 & Gbk_3 & Gbk_4 & Gbk_5 & Gbk_6 & Gbk_7 & Gbk_8 & NASC & PAAS \\
\hline $\begin{array}{l}\text { Depth (m) } \\
\text { range }\end{array}$ & $34.7-35.7$ & $243.5-244.8$ & 341.7 - 342.6 & $573-573.8$ & $590-591$ & $779-780.6$ & 955.5 - 956.5 & 997.9 - 998.8 & & \\
\hline Formation & Benin & Ogwashi-Asaba & Oshosun & Ewekoro & Ewekoro & Ewekoro & Araromi & Araromi & & \\
\hline Lithology & Shale & Shale & Shale & Shale & Shale & Shale & Shale & Shale & & \\
\hline $\mathrm{La}$ & 38.70 & 64.60 & 64.80 & 27.80 & 39.70 & 32.90 & 38.30 & 54.50 & 32 & 38 \\
\hline $\mathrm{Ce}$ & 72.90 & 125.0 & 123.0 & 49.00 & 72.20 & 65.10 & 74.30 & 114.0 & 73 & 80 \\
\hline $\operatorname{Pr}$ & 8.590 & 14.30 & 13.90 & 5.460 & 8.290 & 7.340 & 8.780 & 13.60 & 7.9 & 8.83 \\
\hline $\mathrm{Nd}$ & 31.30 & 52.90 & 50.70 & 19.50 & 30.10 & 27.40 & 32.20 & 52.00 & 33 & 33.9 \\
\hline $\mathrm{Sm}$ & 6.100 & 10.10 & 9.400 & 3.200 & 5.800 & 5.200 & 6.000 & 9.800 & 5.7 & 5.55 \\
\hline $\mathrm{Eu}$ & 1.300 & 2.260 & 2.200 & 0.830 & 1.320 & 1.200 & 1.370 & 2.190 & 1.24 & 1.08 \\
\hline Gd & 4.600 & 7.400 & 7.400 & 2.300 & 4.200 & 4.000 & 4.300 & 7.600 & 5.2 & 4.66 \\
\hline $\mathrm{Tb}$ & 0.700 & 1.200 & 1.200 & 0.400 & 0.700 & 0.600 & 0.700 & 1.100 & 0.85 & 0.77 \\
\hline Dy & 4.300 & 6.600 & 6.200 & 1.900 & 3.500 & 3.300 & 3.600 & 6.100 & 6.2 & 4.68 \\
\hline Но & 0.800 & 1.300 & 1.200 & 0.400 & 0.700 & 0.600 & 0.700 & 1.200 & 1.04 & 0.99 \\
\hline $\mathrm{Er}$ & 2.400 & 3.700 & 3.300 & 1.000 & 2.000 & 1.700 & 1.900 & 3.300 & 3.4 & 2.85 \\
\hline $\mathrm{Tm}$ & 0.380 & 0.550 & 0.490 & 0.160 & 0.280 & 0.250 & 0.300 & 0.480 & 0.5 & 0.4 \\
\hline $\mathrm{Yb}$ & 2.400 & 3.600 & 3.000 & 1.00 & 1.700 & 1.500 & 1.900 & 3.100 & 3.1 & 2.82 \\
\hline $\mathrm{Lu}$ & 0.350 & 0.500 & 0.450 & 0.150 & 0.240 & 0.230 & 0.270 & 0.440 & 0.48 & 0.43 \\
\hline $\mathrm{Y}$ & 24.00 & 38.00 & 37.00 & 11.00 & 20.00 & 18.00 & 18.00 & 37.00 & 27 & - \\
\hline $\mathrm{Eu} / \mathrm{Eu}^{*}$ & 0.720 & 0.764 & 0.778 & 0.891 & 0.780 & 0.774 & 0.786 & 0.747 & & \\
\hline $\mathrm{Eu}^{*}$ & 1.805 & 2.959 & 2.826 & 0.931 & 1.692 & 1.550 & 1.744 & 2.930 & & \\
\hline$\Sigma$ LREE & 157.6 & 266.9 & 261.8 & 105.0 & 156.1 & 137.9 & 159.6 & 243.9 & & \\
\hline$\Sigma$ HREE & 15.93 & 24.85 & 23.24 & 07.31 & 13.32 & 12.18 & 13.67 & 23.32 & & \\
\hline$\Sigma \mathrm{REE}$ & 173.5 & 291.8 & 285.0 & 112.3 & 169.4 & 150.1 & 173.3 & 267.2 & & \\
\hline LREE/HREE & 9.893 & 10.74 & 11.27 & 14.36 & 11.72 & 11.32 & 11.68 & 10.46 & & \\
\hline $\mathrm{La} / \mathrm{Sm}$ & 6.344 & 6.396 & 6.894 & 8.688 & 6.845 & 6.327 & 6.383 & 5.561 & & \\
\hline
\end{tabular}




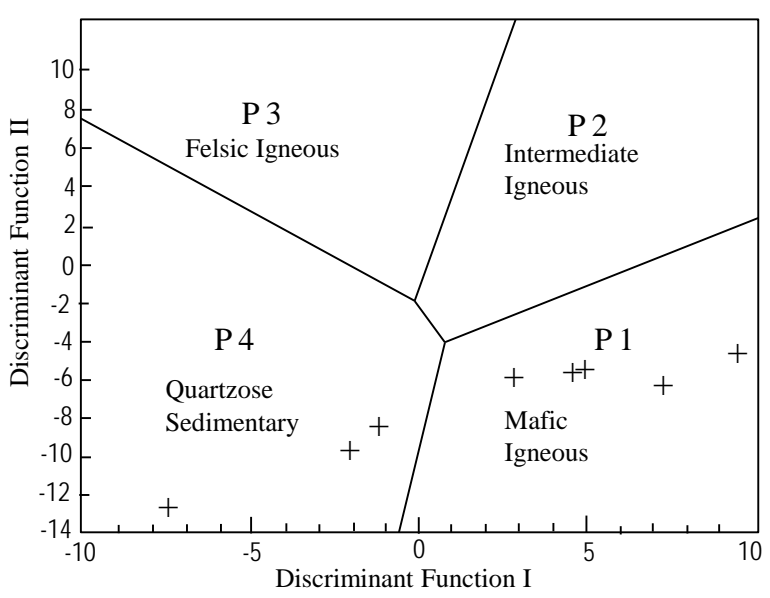

(a)

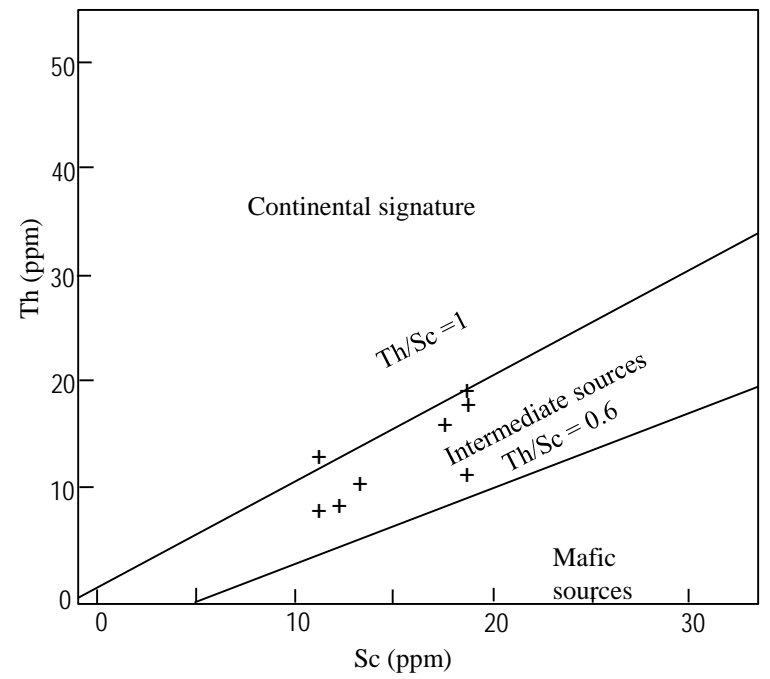

(c)

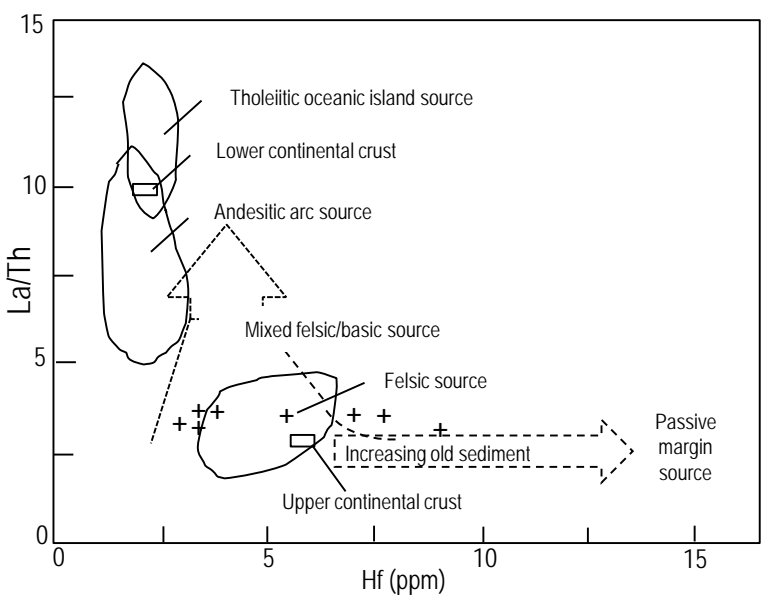

(b)

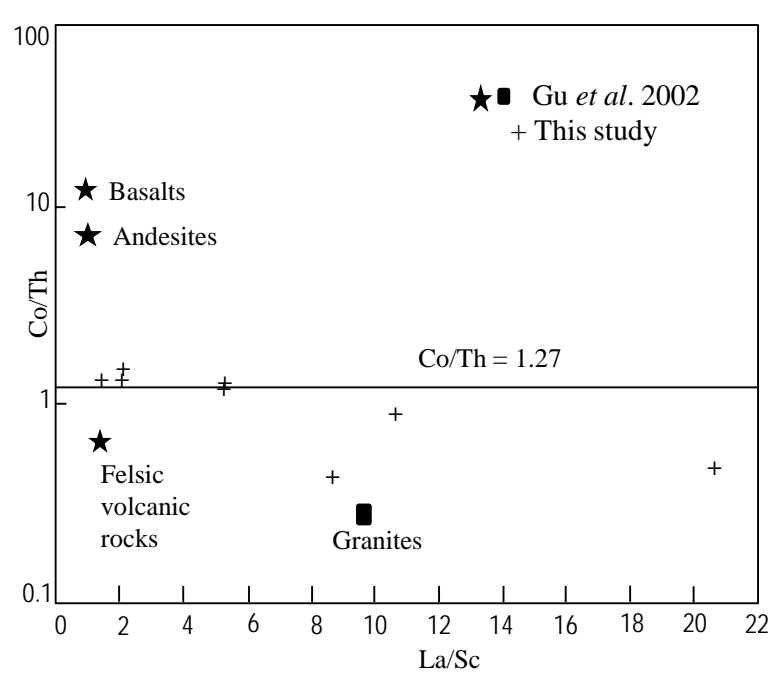

(d)

Figure 5. Discriminant diagrams for provenance of shales from Gbekebo-1 well. (a) Discriminant function diagram after [32]; (b) La/Th-Hf diagram after [34]; (c) Th versus Sc diagram after [3]; (d) Co/Th-La/Sc diagram after [35].

felsic to intermediate igneous source (Figure 5(d)). The chondrite normalization patterns of the REE (Figure 4) marked by a rather flat HREE, LREE enrichment, and a negative Eu anomaly suggestive of a felsic provenance. Negative Eu anomaly represents a differentiated source, related to granite [4].

The major elements suggested mafic igneous to quartzose sedimentary sources, while the trace/REE revealed felsic to mixed sources. This disparity may be attributed to La and Th used in the provenance discrimination exercise, and their abundance in the felsic igneous rocks. However, the source of the Gbekebo- 1 well shales are of old upper continental crust of felsic to intermediate igneous rocks of tonalite to granodiorite compositions with some mafic and Quartzose detrital contributions.

\subsection{Geochemistry and Palaeogeography}

The intensity of weathering and thus the palaeoclimatic condition(s) or the paleogeography of the source area can be inferred from chemical index of alteration (CIA) and chemical index of weathering (CIW). Nesbitt and Young [36] attributed CIA values of about 70 - 75 for shales, while [37] reported CIW values of about 90 - 98 for intensely weathered Archean shales. In this study CIA and CIW values ranged from 82.22 - 96.39 and 88.10 - 99.17 respectively (Table 1). These very high values CIA and CIW are product of $\mathrm{CaO}$ and $\mathrm{Na}_{2} \mathrm{O}$ depletion, a clear indication of intense or prolonged source area weathering probably under tropical conditions. Concentra- 
tions of $\mathrm{Al}_{2} \mathrm{O}_{3}, \mathrm{CaO}+\mathrm{Na}_{2} \mathrm{O}$ and $\mathrm{K}_{2} \mathrm{O}$ in moles of the shale samples from the Gbekebo- 1 well plotted in a ternary diagram (Figure 6) after [1] [38] to estimate the trend of decomposition (chemical weathering), the composition of source rock and the likely effects of metasomatism. The weathering trend paralleled the $\mathrm{Al}_{2} \mathrm{O}_{3}-\mathrm{CaO}+\mathrm{Na}_{2} \mathrm{O}$ line for the fact that $\mathrm{Na}$ and $\mathrm{Ca}$ are leached out by chemical weathering of plagioclase feldspar followed by $\mathrm{K}$-feldspar, liberating $\mathrm{K}$ and tending toward $\mathrm{Al}_{2} \mathrm{O}_{3}$ peak. The weathering trend progressed close to the composition of illite. However, the parallel and non-divergent nature of the trend revealed a possible lack of potassium metasomatism as part of the sedimentary process. The $\mathrm{Al}_{2} \mathrm{O}_{3}-\mathrm{CaO}+\mathrm{Na}_{2} \mathrm{O}-\mathrm{K}_{2} \mathrm{O}$ ternary plot also enabled estimation source rock compositions through a backward projection of weathering trend line to the feldspar line. The point of intersection implies an approximate ratio of plagioclase to k-feldspar in the source rock(s). In this study a tonalite to granodiorite has been suggested, which is related to the composition of the southwestern Nigeria crystalline Basement Complex rocks that comprised gray gneisses of granodioritic to tonalitic composition [39] [40].

\subsection{Geochemistry and Tectonic Setting}

Major elements were applied for provenance discrimination based on plots proposed by [42] and [43]. A plot of $\mathrm{SiO}_{2}$ versus $\log \mathrm{K}_{2} \mathrm{O} / \mathrm{Na}_{2} \mathrm{O}$ (Figure 7(a)) revealed most of the shale samples plotted in the passive margin setting, although one sample plotted in the active continental margin. Furthermore, in the discriminant plot of Bhatia (1983), the shale sample plotted solely in the passive margin setting (Figure 7(b)).

\section{Conclusion}

The provenance characteristics and palaeogeography of the shales from Gbekebo-1 well, southwestern Nigeria have been investigated with geochemical methods. The study revealed that the shales from the Dahomey Embayment were derived mostly from felsic continental sources with some mafic to Quartzose sedimentary input. The provenance characteristics indicated that the Gbekebo-1 shales were deposited on a passive margin setting that received most of its detritus from the nearby southwestern Nigeria Basement Complex rocks. Inferred protoliths (source rocks) from this study consist of tonalite to granodiorite composition subjected to prolong intense chemical weathering likely under a tropical palaeo-climatic condition.

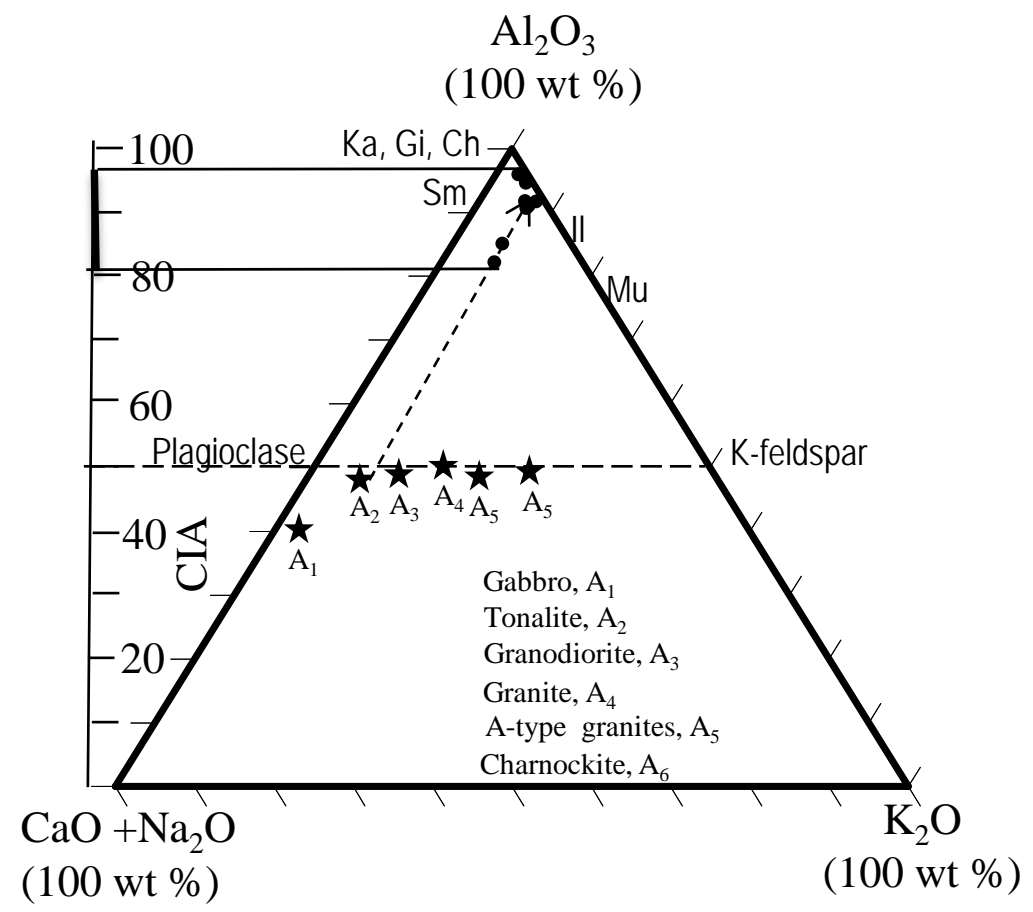

Figure 6. A-CN-K ternary diagram of molar compositions of $\mathrm{Al}_{2} \mathrm{O}_{3}-\left(\mathrm{CaO}+\mathrm{Na}_{2} \mathrm{O}\right)-\mathrm{K}_{2} \mathrm{O}$ for shales from Gbekebo-1 well, after [38]. CIA scale shown on the left side of the figure for comparison. 


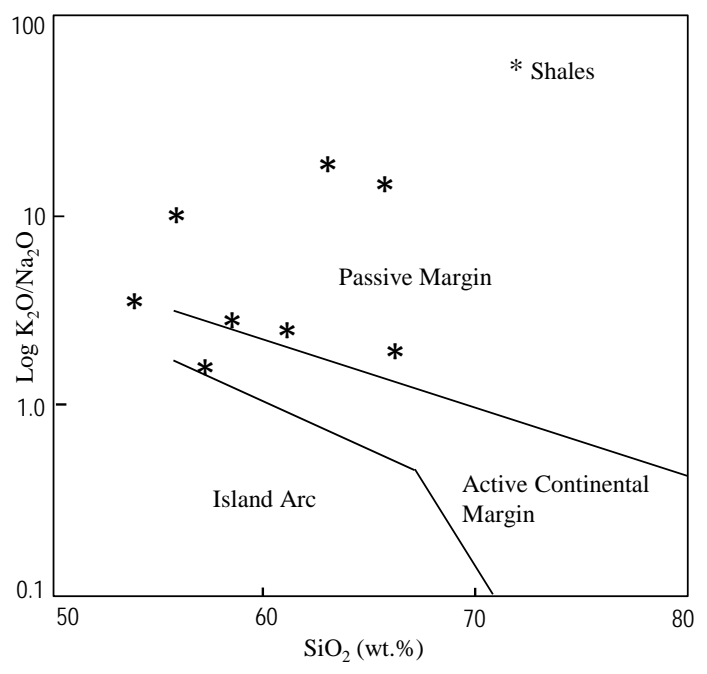

(a)

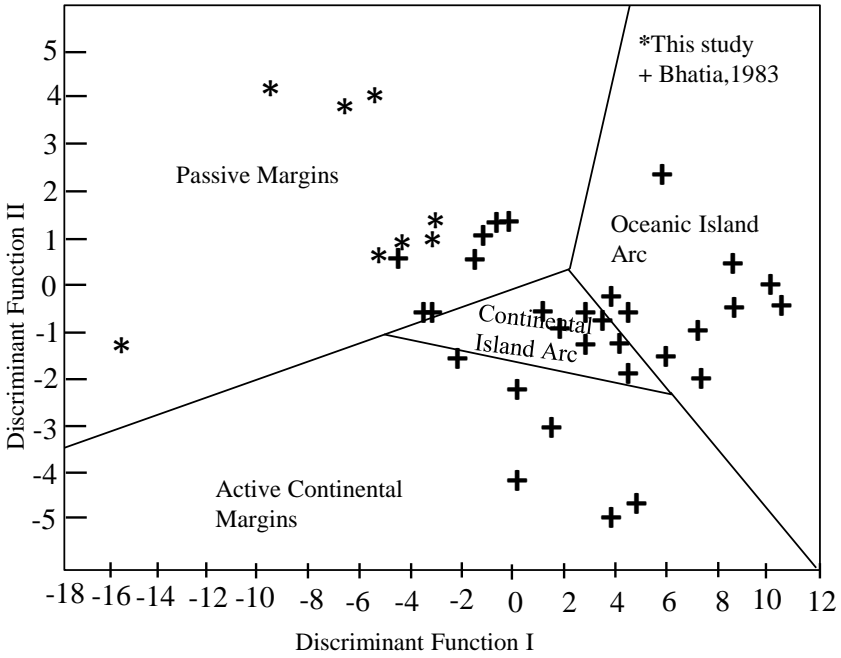

(b)

Figure 7. Major element tectonic setting discrimination diagrams for shales from Gbekebo-1 well. (a) $\log \left(\mathrm{K}_{2} \mathrm{O} / \mathrm{Na}_{2} \mathrm{O}\right)$ versus $\mathrm{SiO}_{2}$, after [42]; (b) Discriminant function diagram, after [43].

\section{Acknowledgements}

The author wish to thank the Nigerian Geological Survey Agency (NGSA) and Activation Laboratory, Canada, for the release of the core samples and analyses respectively. He is also, grateful for the constructive reviews by Prof. I.A. Akpoborie.

\section{References}

[1] Nesbitt, H.W. and Young, G.M. (1989) Formation and Diagenesis of Weathering Profiles. The Journal of Geology, 97, 129-147. http://dx.doi.org/10.1086/629290

[2] Cullers, R.L. and Podkovyrov, V.N. (2000) Geochemistry of the Mesoproterosoic Lakhanda Shales in Southern Yakutia, Russia: Implications for Mineralogical and Provenance Control, and Recycling. Precambrian Research, 104, 77-93. http://dx.doi.org/10.1016/S0301-9268(00)00090-5

[3] McLennan, S.M., Hemming, S.R., McDaniel, D.K. and Hanson, G.N. (1993) Geochemical Approaches to Sedimentation, Provenance, and Tectonics. Geological Society of America, Special Paper, 284, 21-40. http://dx.doi.org/10.1130/SPE284-p21

[4] Taylor, S.R. and McLennan, S.M. (1985) The Continental Crust: Its Composition and Evolution. Blackwell, Oxford, $1-312$.

[5] Ajayi, T.R., Oyawale, A.A., Islander, F.Y., Asubiojo, O.I., Klein, D.E. and Adediran, A.I. (2006) Trace and Rare Earth Elements Geochemistry of Oshosun Sediments of Dahomey Basin, Southwestern Nigeria. Journal of Applied Science, 6, 2067-2076. http://dx.doi.org/10.3923/jas.2006.2067.2076

[6] Okosun, E.A. (1998) Review of the Early Tertiary Stratigraphy of Southwestern Nigeria. Journal of Miming and Geology, 34, 27-35.

[7] Ekweozor, C.M. and Nwachukwu, J.I. (1989) The Origin of Tar Sands of SW, Nigeria. Nigerian Association of Petroleum Explorationists Bulletin, 4, 82-94.

[8] Ekweozor, C.M. (1990) Geochemistry of Oil Sands of SW Nigeria. In: Ako, B.D. and Eni, E.I., Eds., Occurrence, Utilization and Economics of Nigeria tar Sands, Proceedings of NMGS Tar Sand Workshop, Ago-Iwoye, 50-62.

[9] Mosunmolu Ltd. (1991) A Petroleum Geochemical Evaluation of the Dahomey Basin Sediment. 116 p.

[10] Coker, S.J., Adegoke, O.S. and Odeyemi, J.B. (2002) Tar Sand Outcrop Belt, Dahomey Embayment, Field Guide for the NAPE Mini-Conference, Federal University of Technology, Akure, 2002.

[11] Elueze, A.A. and Nton, M.E. (2004) Organic Geochemical Appraisal of Limestones and Shales in Part of Eastern Dahomey Basin, Southwestern Nigeria. Journal of Mining and Geology, 40, 29-40. http://dx.doi.org/10.4314/jmg.v40i1.18806

[12] Coker, S.J., Ejedawe, J.E. and Oshiorienua, J.A. (1983) Hydrocarbon Source Potential of Cretaceous Rocks of Okiti- 
pupa Uplift, Nigeria. Nigerian Journal of Mining Geology, 20, 163-169.

[13] Adegoke, O.S., Enu, E.I., Ajayi, T.R., Ako, B.D., Omatsola, M.E. and Ofonja, A.A. (1981) Tar Sands—A New Energy Raw Material in Nigeria. Proceedings International Symposium on New Energy Raw Materials, Karlory Vary, 17-22.

[14] Brownfield, M.E. and Charpentier, R.R. (2006) Geology and Total Petroleum Systems of the Gulf of Guinea Province of West Africa. U.S. Geological Survey Bulletin 2207-C, 32 p.

[15] Klett, T.R., Ahlbrandt, T.S., Schmoker, J.W. and Dolton, G.L. (1997) Ranking of the World’s Oil and Gas Provinces by Known Petroleum Volumes: U.S. Geological Survey Open-File Report 97-463.

[16] Blarez, E. and Mascle, J. (1988) Shallow Structures and Evolution of the Ivory Coast and Ghana Transform Margin. Marine and Petroleum Geology, 5, 54-64. http://dx.doi.org/10.1016/0264-8172(88)90039-6

[17] Dumestre, M.A. (1985) Northern Gulf of Guinea Shows Promise. Oil \& Gas Journal, 83, 154-165.

[18] Kjemperud, A., Agbesinyale, W., Agdestein, T., Gustafsson, C. and Yükler, A. (1992) Tectono-Stratigraphic History of the Keta Basin, Ghana with Emphasis on Late Erosional Episodes. Bulletin des Centres de Recherches ExplorationProduction Elf-Aquitaine Memoire, 13, 55-69.

[19] Tucker, J.W. (1992) Aspects of the Tano Basin stratigraphy Revealed by Recent Drill in Ghana. Bulletin des Centres de Recherches Exploration-Production Elf-Aquitaine Memoire, 13, 153-159.

[20] Chierici, M.A. (1996) Stratigraphy, Palaeoenvironments and Geological Evolution of the Ivory Coast-Ghana Basin. Bulletin des Centres de Recherches Exploration-Production Elf-Aquitaine Memoire, 16, 293-303.

[21] Adegoke, O.S. (1969) Eocene Stratigraphy of Southern Nigeria. Bulletining Bureau de Research Geologic ET Miners Memoir, 69, 23-48.

[22] Billman, H.G. (1982) Offshore Stratigraphy and Paleontology of the Dahomey (Benin) Embayment, West Africa. Nigerian Association of Petroleum Explorationists Bulletin, 7, 121-130.

[23] Omatsola, M.E. and Adegoke, O.S. (1981) Tectonic Evolution and Cretaceous Stratigraphy of the Dahomey Basin. Journal of Mining and Geology, 18, 130-137.

[24] Enu, E.I. (1987) The Palaeoenvironment of Deposition of the Late Maastrichtian to Paleocene Black Shales in the Eastern Dahomey Basin, Nigeria. Geologie en Mijnbouw, 66, 15-20.

[25] Okosun, E.A. (1990) A Review of the Cretaceous Stratigraphy of the Dahomey Embayment, West Africa. Cretaceous Research, 11, 17-27. http://dx.doi.org/10.1016/S0195-6671(05)80040-0

[26] Ogbe, F.G.A. (1972) Stratigraphy of Strata Exposed in the Ewekoro Quarry, Western Nigeria. In: Dessauvagie, T.F.J. and Whiteman, A.J., Eds., African Geology, University of Ibadan Press, Ibadan, 305-322.

[27] Nwajide, C.S. (2013) Geology of Nigeria’s Sedimentary Basins. CSS Bookshop Ltd., Lagos, 1-565.

[28] Jarvis, I. and Jarvis, K.E. (1995) Plasma Spectrometry in Earth Sciences: Techniques, Applications and Future Trends. Chemical Geology, 95, 1-33.

[29] Jarvis, K.E. (1988) Inductively Coupled Plasma Mass Spectrometry: A New Technique for the Rapid or Ultra-Trace Level Determination of the Rare-Earth Elements in Geological Materials. Chemical Geology, 68, 31-39. http://dx.doi.org/10.1016/0009-2541(88)90084-8

[30] Gromet, L.P., Dymek, R.F., Haskin, L.A. and Korotev, R.V. (1984) The North American Shale Composite: Its Composition, Major and Trace Element Characteristics. Geochimica et Cosmochimica Acta, 48, 2469-2482. http://dx.doi.org/10.1016/0016-7037(84)90298-9

[31] Herron, M.M. (1988) Geochemical Classification of Terrigenous Sands and Shales from Core or Log Data. Journal of Sedimentary Petrology, 58, 820-829.

[32] Roser, B.P. and Korsch, R.J. (1988) Provenance Signature of Sandstone-Mudstone Suites Determined Using Discriminant Function Analysis of Major Element Data. Chemical Geology, 67, 119-139. http://dx.doi.org/10.1016/0009-2541(88)90010-1

[33] Hayashi, K., Fujisawa, H., Holland, H.D. and Ohmoto, H. (1997) Geochemistry of 1.9 Ga Sedimentary Rocks from Northeastern Labrador, Canada. Geochimica et Cosmochimica Acta, 61, 4115-4137. http://dx.doi.org/10.1016/S0016-7037(97)00214-7

[34] Floyd, P.A. and Leveridge, B.E. (1987) Tectonic Environment of the Devonian Gramscatho Basin South Cornwall: Framework Mode and Geochemical Evidence from Turbiditic Sandstones. Journal of the Geological Society (London), 144, 531-542. http://dx.doi.org/10.1144/gsjgs.144.4.0531

[35] Gu, X.X., Liu, J.M., Zheng, M.H., Tang, J.X. and Qi, L. (2002) Provenance and Tectonic Setting of the Proterozoic Turbidites in Hunan, South China: Geochemical Evidence. Journal of Sedimentary Research, 72, 393-407. http://dx.doi.org/10.1306/081601720393

[36] Nesbitt, H.W. and Young, G.M. (1982) Early Proterozoic Climates and Plate Motions Inferred from Major Element 
Chemistry of Lutites. Nature, 299, 715-717. http://dx.doi.org/10.1038/299715a0

[37] Condie, K.C. (1993) Chemical Composition and Evolution of Upper Continental Crust: Contrasting Results from Surface Samples and Shales. Chemical Geology, 104, 1-37. http://dx.doi.org/10.1016/0009-2541(93)90140-E

[38] Nesbitt, H.W. and Young, G.M. (1984) Prediction of Some Weathering Trends of Plutonic and Volcanic Rocks Based on Thermodynamic and Kinetic Considerations. Geochimica et Cosmochimica Acta, 48, 1523-1534. http://dx.doi.org/10.1016/0016-7037(84)90408-3

[39] Burke, K., Freeth, S.J. and Grant, N.K. (1976) The Sequence of Geological Events in the Basement Complex of the Ibadan Area, Western Nigeria. Precambrian Research, 3, 537-545. http://dx.doi.org/10.1016/0301-9268(76)90017-6

[40] Petters, S.W. (1991) Regional Geology of Africa. Springer-Verlag, Berlin. http://dx.doi.org/10.1007/BFb0020577

[41] Petters, S.W. and Olsson, R.K. (1979) Planktonic Foraminifera from the Ewekoro Type Section (Paleocene) Nigeria. Micropaleontology, 25, 206-213. http://dx.doi.org/10.2307/1485267

[42] Roser, B.P. and Korsch, R.J. (1986) Determination of Tectonic Setting of Sandstone-Mudstone Suites Using $\mathrm{SiO}_{2}$ Content and $\mathrm{K}_{2} \mathrm{O} / \mathrm{Na}_{2} \mathrm{O}$ Ratio. The Journal of Geology, 94, 635-650. http://dx.doi.org/10.1086/629071

[43] Bhatia, M.R. (1983) Plate Tectonics and Geochemical Composition of Sandstone. The Journal of Geology, 91, 611627. http://dx.doi.org/10.1086/628815

\section{Submit or recommend next manuscript to SCIRP and we will provide best service for you:}

Accepting pre-submission inquiries through Email, Facebook, Linkedin, Twitter, etc A wide selection of journals (inclusive of 9 subjects, more than 200 journals)

Providing a 24-hour high-quality service

User-friendly online submission system

Fair and swift peer-review system

Efficient typesetting and proofreading procedure

Display of the result of downloads and visits, as well as the number of cited articles

Maximum dissemination of your research work

Submit your manuscript at: http://papersubmission.scirp.org/ 